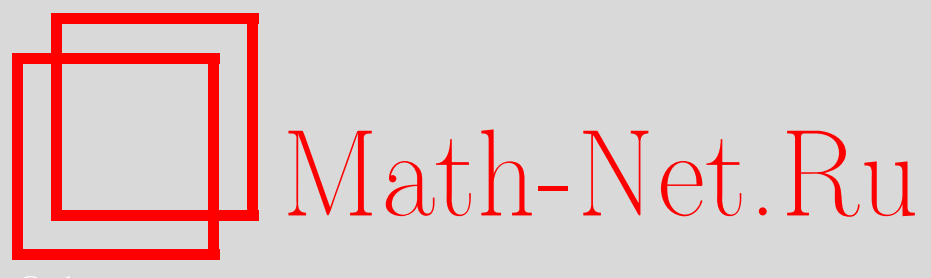

Э. Л. Аким, В. И. Арнольд, В. В. Белецкий, И. Г. Горячева, В. Ф. Жууравлев, Д. М. Климов, В. В. Козлов, О. Б. Лупанов, С. П. Новиков, Ю. П. Попов, В. В. Румянцев, Ф. Л. Черноусько, Г. Г. Черный, Т. М. Энеев, Дмитрий Евгеньевич Охоцимский (некролог), УМH, 2006, том 61, выпуск 3, 157-160

DOI: https://doi.org/10.4213/rm1749

Использование Общероссийского математического портала Math-Net.Ru подразумевает, что вы прочитали и согласны с пользовательским соглашением http://www . mathnet.ru/rus/agreement

Параметры загрузки:

IP : 54.224 .187 .69

26 апреля 2023 г., 16:56:47

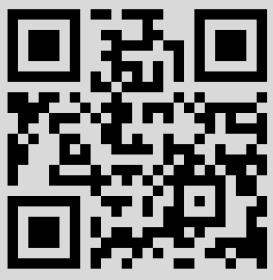




\section{Дмитрий Евгеньевич Охоцимский}

В ночь с 17 на 18 декабря 2005 г. после тяжелой продолжительной болезни скончался академик Дмитрий Евгеньевич Охоцимский - выдающийся ученый и организатор науки в области механики, математики и теории управления.

Дмитрий Евгеньевич родился 26 февраля 1921 г. в Москве и окончил механико-математический факультет Московского государственного университета им. М.В.Ломоносова (1946). Еще будучи студентом он был увлечен проблемами движения ракет, с которыми познакомился на семинаре замечательного педагога, ученого и энтузиаста ракетодинамики профессора А. А. Космодемьянского (1909-1988) ${ }^{1}$. Первая научная работа Д. Е. Охоцимского "K теории движения ракет" была опубликована в журнале "Прикладная математика и механика". В этой работе предлагался оригинальный подход к решению вырожденных вариационных задач, основанный на прямом исследовании вариаций уравнений движения. Эта работа имела применение к оптимизации траек-

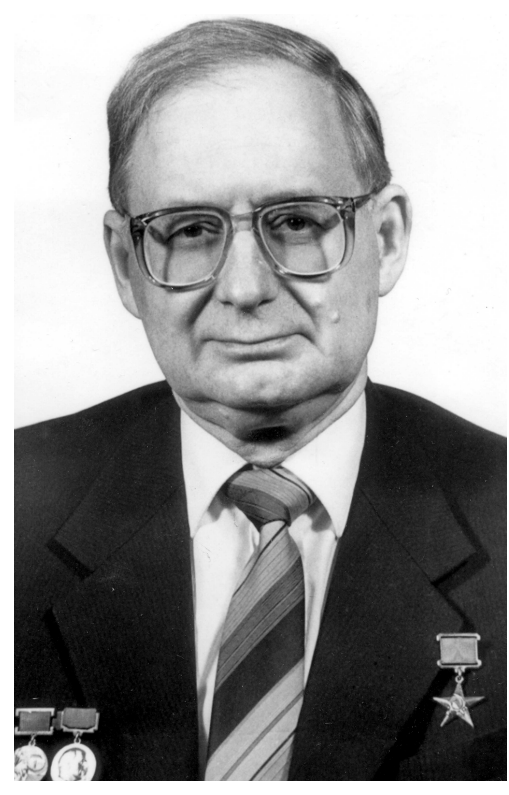
торий ракет и сразу привлекла внимание исследователей.

После окончания университета Дмитрий Евгеньевич был зачислен в аспирантуру Математического института им. В.А. Стеклова АН СССР. Аспирантской работой Дмитрия Евгеньевича руководил академик Мстислав Всеволодович Келдыш. В 1949 г. Дмитрий Евгеньевич защитил кандидатскую диссертацию и остался работать в институте в отделе М. В. Келдыша.

Сам Дмитрий Евгеньевич вспоминает о начале своей деятельности в МИАН:

“... Довольно скоро в МИАН начали развертываться работы по ракетной тематике. .. Первые наши работы должны были подвести теоретическую базу под то, какие нужно делать ракеты, как надо их проектировать, каковы их возможности. К этим работам Мстислав Всеволодович сразу же подключил меня и небольшой коллектив из выпускников университета и других людей, который мне, по его просьбе, удалось сформировать. В него входили С. С. Камынин, Т. М. Энеев, В. А. Егоров, потом появился В.А. Сарычев. Так родилась ячейка, занимавшаяся и крылатыми ракетами, и баллистическими ракетами. Первые исследования и расчеты были выполнены в 1946 г.

\footnotetext{
${ }^{1}$ Наряду с Д. Е. Охоцимским из участников этого семинара вырос ряд крупнейших теоретиков ракетодинамики и космического полета, среди которых Т. М. Энеев (род. 1924), В. В. Белецкий (род. 1930), В. А. Егоров (1930-2001), В. А. Сарычев (род. 1931).
} 
Когда в 1953 г. организовывалось Отделение прикладной математики, Мстислав Всеволодович предложил мне перейти в ОПМ вместе с коллективом в качестве руководителя отдела. . . Исследования по нашей тематике здесь проводились всегда; сперва они были направлены на развитие ракетной техники, а затем, когда в воздухе повеяло возможностью космических запусков, мы с самого начала подключились к этим делам. ..".

(Заметим, что Дмитрию Евгеньевичу предстояло проработать в ОПИ-ИПМ свыше полувека.)

Далее Дмитрий Евгеньевич пишет:

“... В 1954 г., когда уже стало ясным, что приближается время космической эры, она уже стучится в дверь, Мстислав Всеволодович созвал совещание ученых и руководителей ракетной техники в своем рабочем кабинете в нашем Институте, где сейчас находится кабинет-музей академика М. В. Келдыша. Это историческое совещание! Мы с Тимуром Магометовичем Энеевым принимали в нем участие... Присутствовали С. П. Королев, П. Л. Капица, И. А. Кибель, М. К. Тихонравов, А. Ю. Ишлинский, С. Н. Вернов и целый ряд других людей. ..".

В.А. Егоров в своих воспоминаниях ${ }^{2}$ называет еще ряд лиц, приглашенных и присутствовавших на этом историческом совещании (Л. И. Седов и др.) и особо отмечает, что М. В. Келдыш счел нужным пригласить и молодых аспирантов - В. А. Егорова (которому доверили вести протокол) и В. А. Сарычева. Да и сам Дмитрий Евгеньевич был тогда молод (33 года) и из всех будущих ученых званий и наград имел только ученую степень кандидата физико-математических наук.

Видимо, в результате дискуссии на этом совещании с академиком П. Л. Капицей у Дмитрия Евгеньевича родилась идея пассивной гравитационной стабилизации искусственных спутников Земли, т.е. ориентации спутников за счет природных сил без всяких затрат топлива на управление ориентацией. Много позже (в 1970 г.) Дмитрий Евгеньевич с коллективом исследователей был удостоен Государственной премии за работы в этой области.

Пятидесятые годы - годы подготовки и реализации прорыва в космос - были годами невиданного взлета инициированных и руководимых М. В. Келдышем научных исследований в Институте прикладной математики вообще и в отделе Д. Е. Охоцимского в том числе. Созданный и руководимый Д. Е. Охоцимским отдел прошел триумфальный путь научных свершений, которые носят новаторский характер, направлены на решение конкретных научно-технических проблем и выполнены на высочайшем научном уровне.

Речь идет не только об исследовании проблем, связанных с освоением космического пространства. Можно назвать, например, работу Д. Е. Охоцимского о движении тела с полостями, частично заполненными жидкостью (баки ракет, например). Или новаторскую работу о сильном взрыве, давшую новое представление о протекающих при этом процессах.

Но основным полем деятельности Д. Е. Охоцимского и его сотрудников на многие годы стало исследование проблем динамики космического полета.

Школа динамики космического полета Келдыша-Охоцимского теперь всемирно известна. Стоит вспомнить, например, имена блестящих исследователей траекторий полетов к Луне - сотрудников и соратников Д. Е. Охоцимского В. А. Егорова и М. Л. Лидова (увы, тоже уже ушедших в мир иной).

\footnotetext{
${ }^{2}$ В. А. Егоров, “M. В. Келдыш - мой учителъ”, М. В. Келдыш. Творческий портрет в воспоминаниях современников, Наука, М., 2001, с. 373.
} 
Приоритетными и эпохальными были работы Д. Е. Охоцимского и его соавторов Т. М. Энеева и Г. П. Таратыновой о вариационных задачах, связанных с запуском искусственных спутников Земли, и об орбитальной динамике искусственного спутника Земли.

Опубликованные в знаменитом номере журнала "Успехи физических наук" за 1957 г. (т. 63, № 1a), эти и другие работы предшествовали запуску первого искусственного спутника Земли (4 октября 1957 г.). Какое это произвело впечатление на человечество - хорошо известно.

Большой коллектив, обеспечивший запуск первого искусственного спутника Земли, в том числе и Дмитрий Евгеньевич, был удостоен Ленинской премии (1957).

Руководимый Д. Е. Охоцимским коллектив непосредственно участвовал в подготовке и осуществлении полета первого человека в космос и первых автоматических аппаратов, запускаемых к Луне и планетам Солнечной системы. В этом коллективе выросли под непосредственным руководством Дмитрия Евгеньевича 35 кандидатов и 12 докторов наук; кроме самого Дмитрия Евгеньевича еще двое его соратников были избраны в РАН (академик Т. М. Энеев и член-корреспондент РАН В. В. Белецкий).

Сам Дмитрий Евгеньевич продолжал активно лично заниматься актуальными задачами динамики космического полета. В круг его исследований входили проблемы полета космических аппаратов с двигателями малой тяги, важнейшая для пилотируемых космических аппаратов проблема спуска с орбиты на Землю.

В 1959 г. Д. Е. Охоцимский, без отрыва от основной работы в Институте прикладной математики, стал (по инициативе Н. Г. Четаева) профессором кафедры теоретической механики на механико-математическом факультете МГУ им. М. В. Ломоносова, а в 1962 г. возглавил эту кафедру и руководил ею до конца своих дней.

Под руководством Дмитрия Евгеньевича кафедра, получившая позже (в 1999 г.) название "кафедра теоретической механики и мехатроники", сильно расширила тематику своей деятельности. Дмитрий Евгеньевич пригласил на кафедру ряд сотрудников Института прикладной математики и смежных организаций. Это позволило создать новые направления деятельности; заинтересовать и привлечь студентов, аспирантов и сотрудников кафедры к исследованию широкого круга проблем динамики и управления, небесной механики, а позже - мехатроники; ввести новые спецкурсы, один из которых Дмитрий Евгеньевич читал сам. ${ }^{3}$

Первое чтение этого курса "Динамика космического полета" (в 1961 г.) имело огромный успех: потоковая аудитория 16-10 Главного здания МГУ была полна.

С 1970 г. по инициативе Д.Е. Охоцимского были начаты работы по принципиально новой тематике - созданию транспортных средств нового типа: шагающих аппаратов. Эта тематика расширилась и стала составной частью целевой программы научно-исследовательских работ по комплексной программе "робототехнические системы". Разработка методов управления шестиногими и двуногими шагающими аппаратами велась с 1970 г. в Институте прикладной математики им. М. В. Келдыша, Институте механики МГУ, Институте проблем передачи информации, на кафедре теоретической механики и мехатроники МГУ под руководством Д. Е. Охоцимского. Были разработаны методы математического моделирования, основанные на использовании современной вычислительной техники. С их помощью созданы алгоритмы построения движения аппарата, позволяющие обеспечивать устойчивость при преодолении препятствий, прыжках, регулярном движении и маневрировании. Были созданы лабораторные макеты шагающих аппаратов, сопряженных с ЭВМ, снабженных электромеханическими приводами и системой технического зрения.

\footnotetext{
${ }^{3}$ Д. Е. Охоцимский, Ю. Г. Сихарулидзе, Основъ механики космического полета: Учебное пособие, Наука, М., 1990.

${ }^{4}$ Механика в Московском университете, под ред. И.А. Тюлиной и Н. Н. Смирнова. Айрис-Пресс, М., 2005.
} 
С 1998 г. в МГУ на базе Института механики проводятся ежегодные научно-технические фестивали молодежи "Мобильные роботы", включающие соревнования интеллектуальных мобильных роботов, созданных коллективами студентов, аспирантов, преподавателей и научных сотрудников различных вузов и учреждений. Существуют и международные соревнования такого типа, на которых успешно выступали российские коллективы, руководимые Д. Е. Охоцимским.

Кроме непосредственной научной и научно-преподавательской деятельности Д.Е. Охоцимский успевал на официальном уровне заниматься крупномасштабной научно-организационной деятельностью как член Национального комитета по теоретической и прикладной механике, председатель Научно-технического комитета по робототехнике и мехатронике, председатель специализированного совета по теоретической механике при МГУ.

Научная и научно-организационная деятельность Д. Е. Охоцимского была отмечена многими высокими званиями и наградами. Он был членом РАН (членом-корреспондентом с 1960 и действительным членом с 1991), лауреатом Ленинской премии (1957), Государственной премии СССР (1970), премии им. С. А. Чаплыгина АН СССР (1951), он был награжден Золотой медалью имени М. В. Келдыша РАН (2001); его имя присвоено Международным Астрономическим союзом одной из малых планет Солнечной системы (2001); он был удостоен звания Героя Социалистического Труда (1961), награжден орденами Ленина $(1956,1961)$, Трудового Красного Знамени (1970, 1981), Октябрьской Революции (1975).

Дмитрий Евгеньевич был неординарным человеком. Требовательный, если надо жестко требовательный к делу; мягкий, доброжелательный в неофициальной обстановке, ценящий шутку и юмор; сам умел удачно шутить (если работа идет хорошо).

Не обижался на шутки в свой адрес. Вот пример такой шутки, под названием "Три принципа Д.Е.”, приведенной в книге В. В. Белецкого ${ }^{5}$ :

Первый принцип Д.Е. Подчиненный не имеет никаких претензий к опозданиям начальника на встречу, так как понимает, что у начальника есть дела более важные, чем встреча с подчиненным.

Второй принцип Д. Е. Хвалить подчиненного, если он того заслужил, бесполезно для дела, так как дело и без того идет хорошо.

Третий принцип Д. Е. Ругать подчиненного, если он того заслужил, полезно для дела.

Шутки шутками, однако, существует еще и:

Главный принцип Д..$^{6}$ Дело требует всестороннего и подробного обсуждения постановки проблемы, методов ее исследования, целей этого исследования, предсказания возможных и желательных результатов и способов оптимизации этих результатов. На это время не жалеть!

Интеллектуальная мощь и организаторский талант Дмитрия Евгеньевича Охоцимского лежали в основе не одного знаменитого достижения Российской науки.

Дмитрий Евгеньевич не дожил чуть больше двух месяцев до своего 85-летия. Его кончина - невосполнимая утрата для его родных, друзей, коллег и для всей российской и мировой науки.

Э. Л. Аким, В.И. Арнолъд, В. В. Белецкий, И. Г. Горячева, В. Ф. Журавлев, Д. М. Климов, В.В. Козлов, О.Б. Лупанов, С.П. Новиков, Ю.П. Попов, В.В. Румянцев, Ф. Л. Черноусъко, Г.Г. Черный, Т. М. Энеев

\footnotetext{
${ }^{5}$ В. В. Белецкий, “Шестъ дюжин”, Институт компьютерных исследований, М.-Ижевск, 2005.

${ }^{6}$ См. ту же книгу В. В. Белецкого.
} 